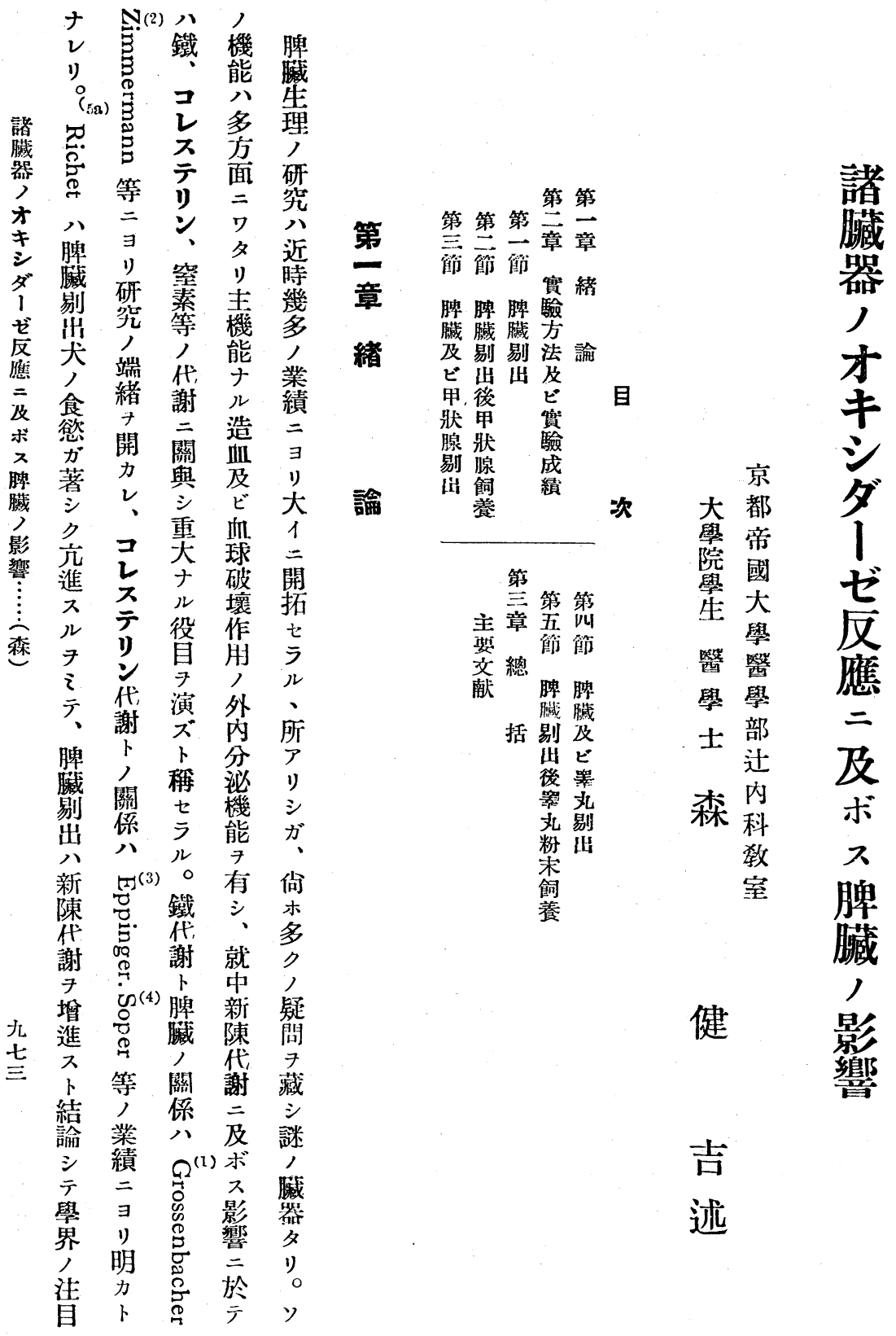




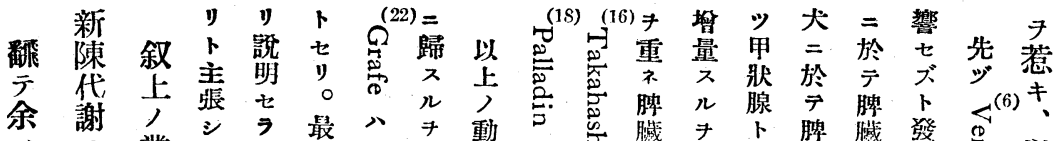

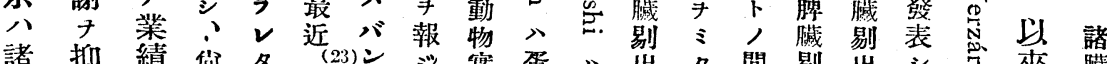
諸抑績 倾夕.

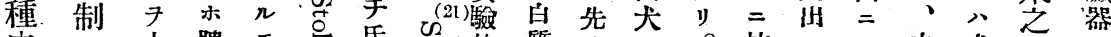

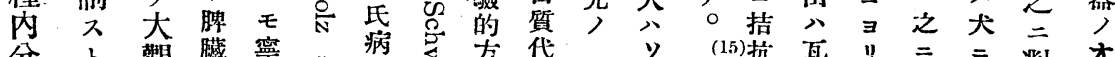

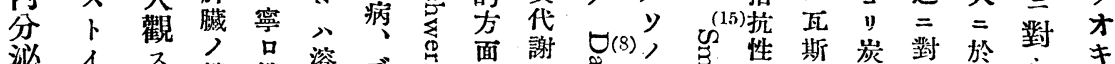

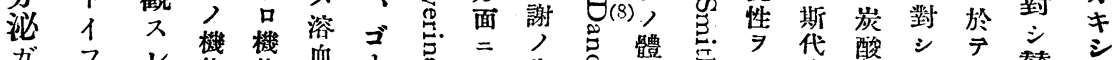
ガ藏 モ バ能能 性

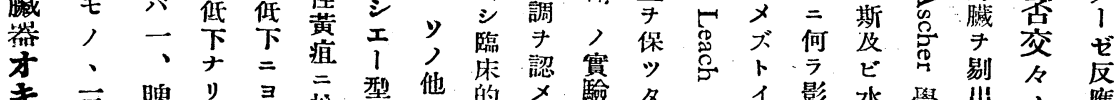
キ 三脾 ダ 境 藏 士分新 、明礎

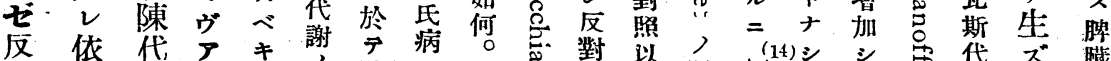

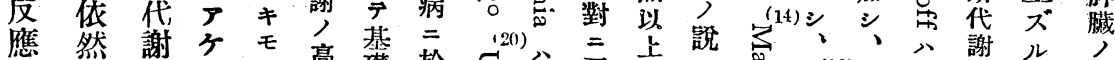

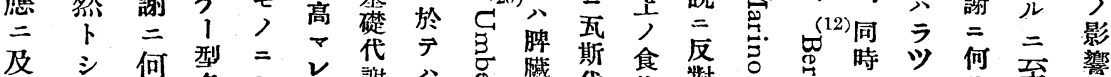

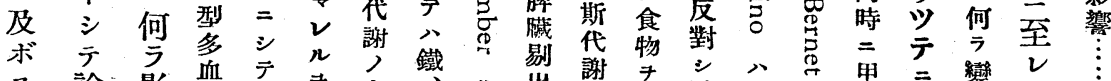

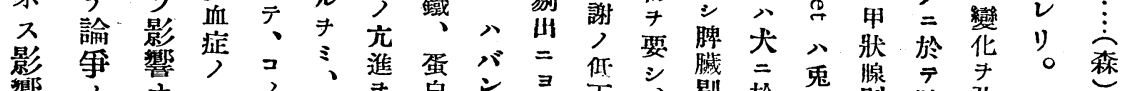

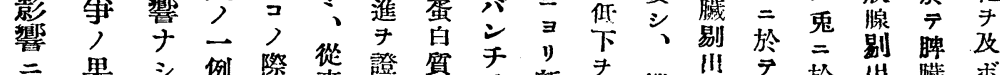

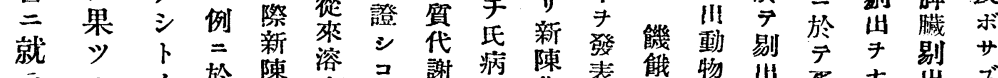

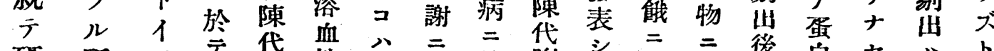

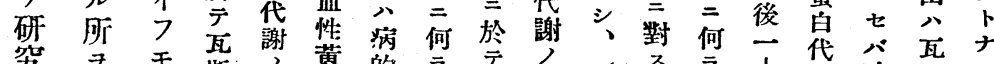

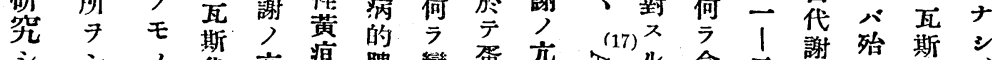

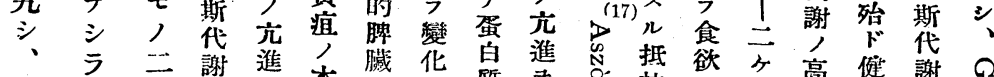

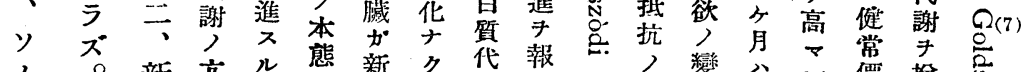

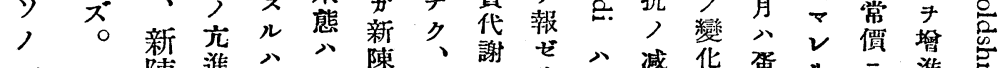

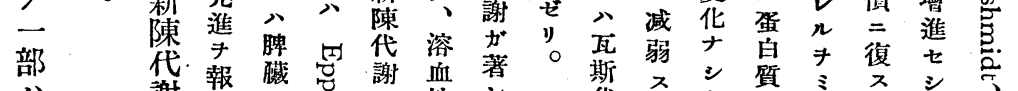
八 既 謝

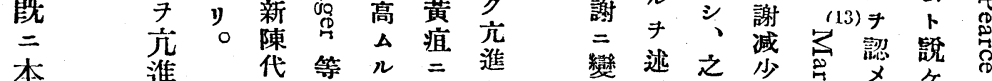
本 進 代 等 $n=$ 迶 於

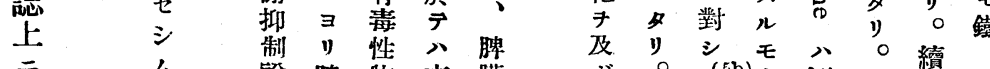

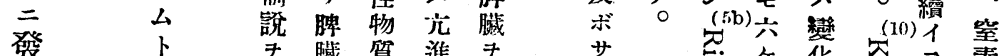

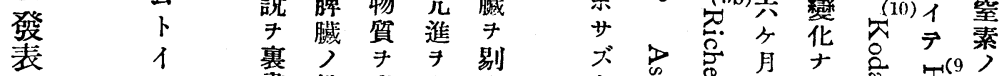

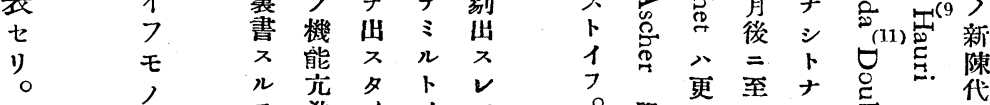

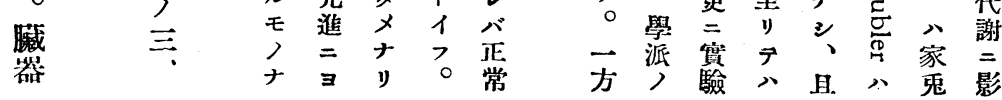




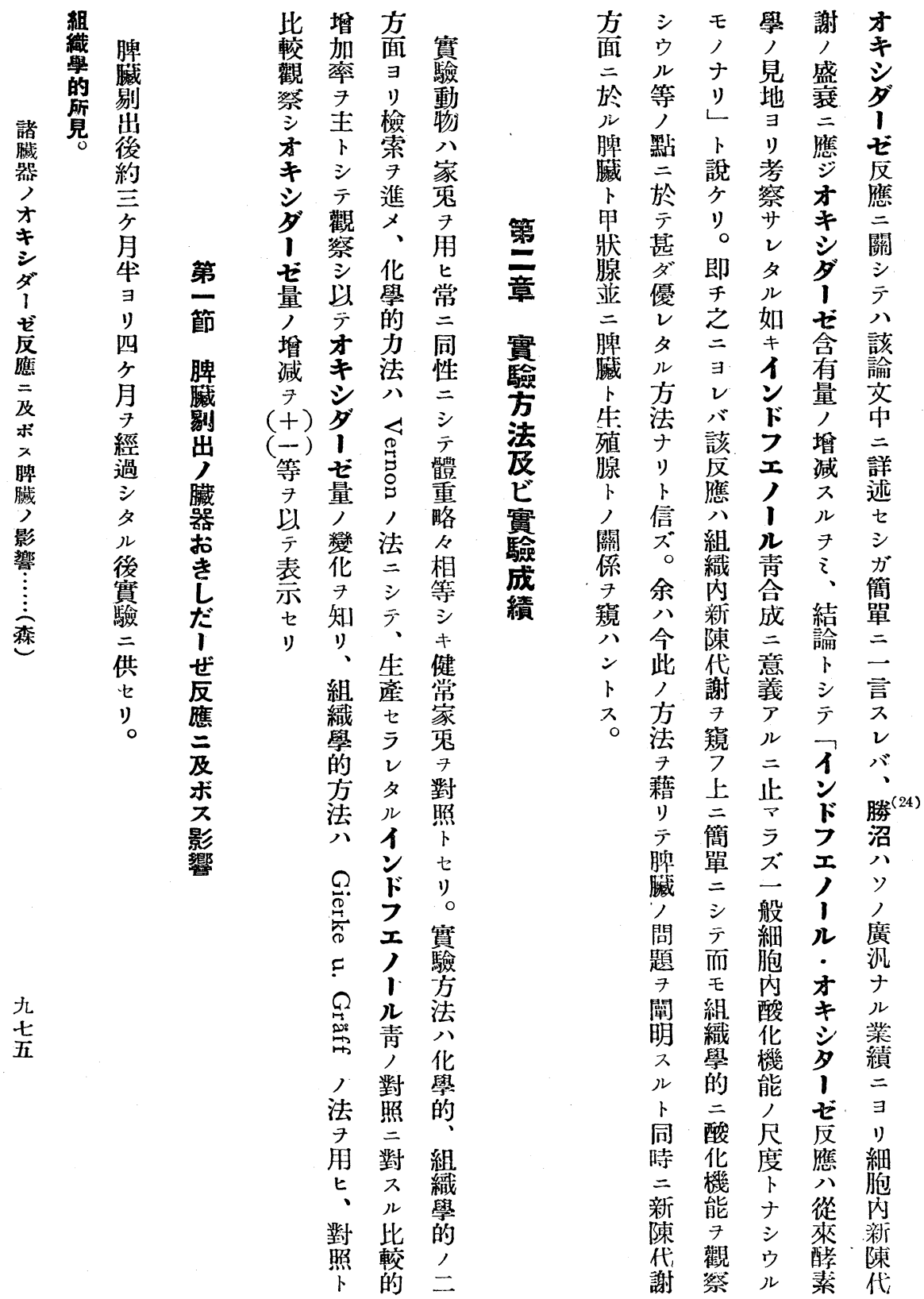


第一表 膙臟剔汕家鬼二於タル實驗

\begin{tabular}{|c|c|c|c|c|c|c|c|c|c|c|c|c|c|c|}
\hline \multicolumn{2}{|c|}{ 臟 } & 器 & \multicolumn{2}{|c|}{ 心 } & 臟 & \multicolumn{2}{|c|}{ 筒 } & 歲 & \multicolumn{2}{|c|}{ 脏 } & 蔵 & \multicolumn{2}{|l|}{ 碳 } & 洘 \\
\hline 番 & $\|$ 家 & 性 & 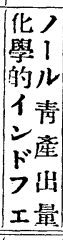 & \begin{tabular}{|c|} 
同 \\
箸 \\
减 \\
率 \\
$(\%)$
\end{tabular} & $\begin{array}{l}\text { 組 } \\
\text { 織 } \\
\text { 學 } \\
\text { 的 }\end{array}$ & 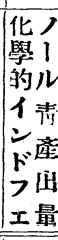 & $\begin{array}{c}\text { 同 } \\
\text { 增 } \\
\text { 减 } \\
\text { 率 } \\
(\%)\end{array}$ & $\begin{array}{l}\text { 組 } \\
\text { 織 } \\
\text { 學 } \\
\text { 的 }\end{array}$ & 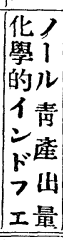 & \begin{tabular}{|c|} 
同 \\
增 \\
减 \\
率 \\
$(\%)$
\end{tabular} & $\begin{array}{l}\text { 組 } \\
\text { 織 } \\
\text { 學 } \\
\text { 的 }\end{array}$ & $\begin{array}{l}\text { 剔 } \\
\text { 出 } \\
\text { 前 } \\
\text { 蹬 } \\
\text { 重 }\end{array}$ & $\begin{array}{l}\text { 試 } \\
\text { 驗 } \\
\text { 時 } \\
\text { 體 } \\
\text { 重 }\end{array}$ & $\begin{array}{l}\text { 剔 } \\
\text { 出 } \\
\text { 後 } \\
\text { 經 } \\
\text { 過 } \\
\text { 日 } \\
\text { 䗆 } \\
\end{array}$ \\
\hline I & 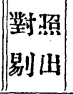 & $\begin{array}{l}\hat{\delta} \\
\hat{\delta}\end{array}$ & $\begin{array}{r}9.9 \\
10.4\end{array}$ & +5.1 & -1 & $\begin{array}{l}7.8 \\
7.5\end{array}$ & -3.8 & -1 & $\begin{array}{l}5.0 \\
5.6\end{array}$ & +12.0 & \pm & 2.200 & $\begin{array}{l}2.000 \\
2.300\end{array}$ & 104 \\
\hline 『 & 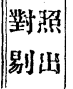 & $\begin{array}{l}\hat{\delta} \\
\hat{\delta}\end{array}$ & $\begin{array}{l}10.7 \\
11.2\end{array}$ & +4.7 & \pm & $\begin{array}{l}7.9 \\
7.9\end{array}$ & 0 & \pm & $\begin{array}{l}4.1 \\
5.8\end{array}$ & +41.5 & +1 & 1.400 & $\begin{array}{l}2.000 \\
1.600\end{array}$ & 103 \\
\hline III & 對照 & $\begin{array}{l}q \\
q\end{array}$ & $\begin{array}{r}7.5 \\
10.5\end{array}$ & +40.0 & \pm & $\begin{array}{l}5.9 \\
5.0\end{array}$ & -15.3 & -1 & $\begin{array}{l}4.0 \\
4.3\end{array}$ & +7.5 & +1 & 1.700 & $\begin{array}{l}2.350 \\
2.100\end{array}$ & 122 \\
\hline IV & $\left|\begin{array}{l}\text { 對照 } \\
\text { 剔出 }\end{array}\right|$ & $\begin{array}{l}\hat{\delta} \\
\hat{\delta}\end{array}$ & $\begin{array}{r}7.2 \\
9.0\end{array}$ & +25.0 & +1 & $\begin{array}{l}4.4 \\
4.9\end{array}$ & +11.4 & \pm & $\begin{array}{l}3.5 \\
3.9\end{array}$ & +11.4 & +1 & 2.400 & $\begin{array}{l}1.900 \\
1.700\end{array}$ & 109 \\
\hline V & $\left|\begin{array}{l}\text { 對照 } \\
\text { 剔出 }\end{array}\right|$ & $\begin{array}{l}q \\
\text { o }\end{array}$ & $\begin{array}{l}7.7 \\
9 \cdot 0\end{array}$ & $\begin{array}{r} \\
+16.9 \\
\end{array}$ & 上 & $\begin{array}{l}3.6 \\
4.7\end{array}$ & +30.6 & \pm & $\begin{array}{l}2.4 \\
3.1\end{array}$ & +29.2 & +1 & 2.100 & $\begin{array}{l}1.750 \\
2.000\end{array}$ & 111 \\
\hline 平均 & $\left|\begin{array}{l}\text { 對照 } \\
\text { 剔山 }\end{array}\right|$ & & $\left|\begin{array}{r}86 \\
10.0\end{array}\right|$ & +16.5 & . & $\begin{array}{l}5.9 \\
6.0\end{array}$ & +1.4 & & $\begin{array}{l}3.8 \\
4.5\end{array}$ & +19.4 & & & & \\
\hline
\end{tabular}

IV

III

II

I

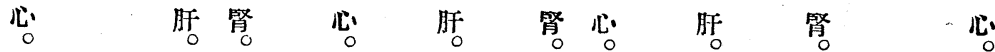

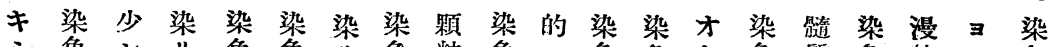

色 シ 》色色》色粒色二色色 キ色質色的》色

名速。、速速、速、速咀速速济速洪速二稍速

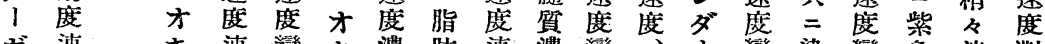

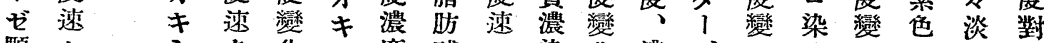

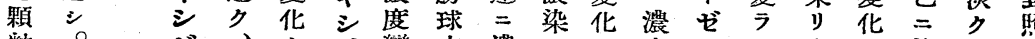

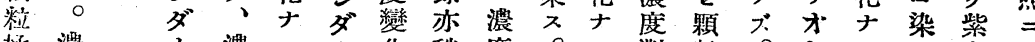

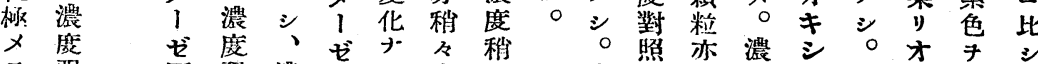

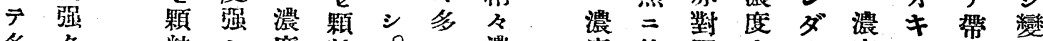

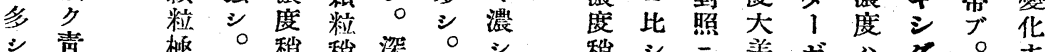

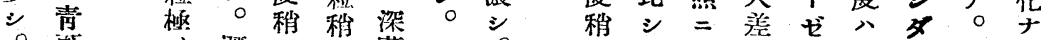

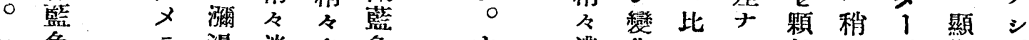

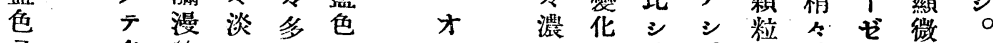

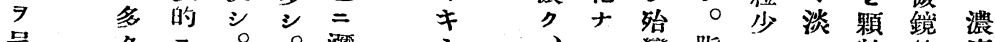

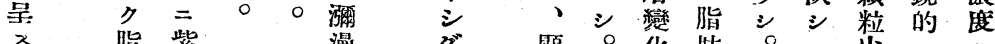

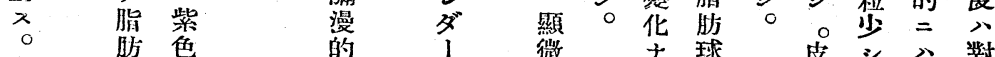

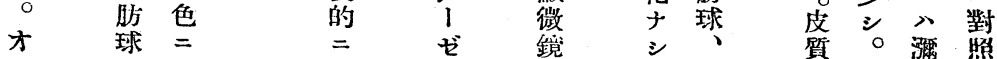


完 豆 (')

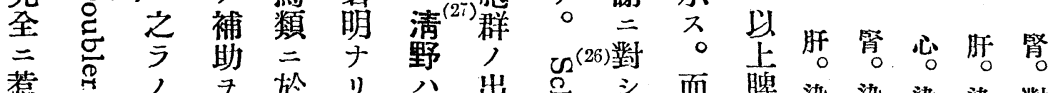
諸起等默与等

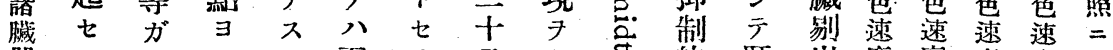

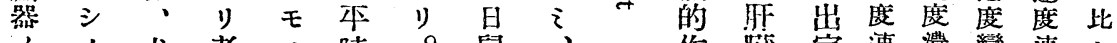

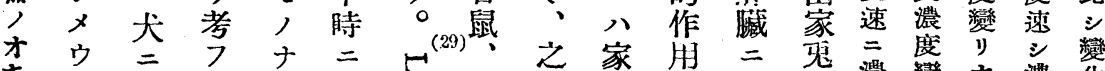

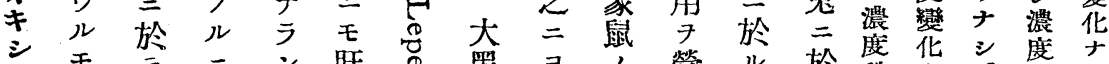

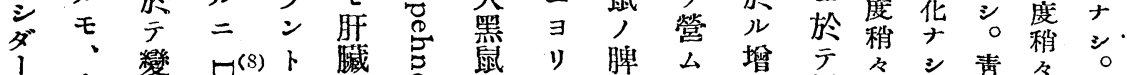

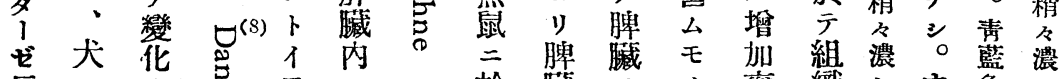

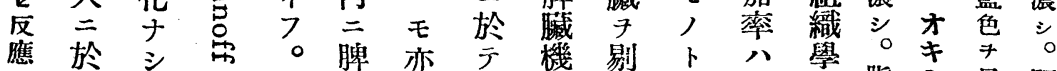

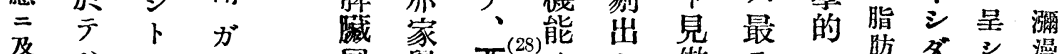

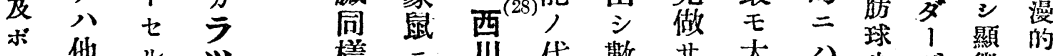

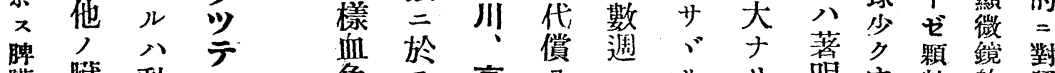
臓䁍動二色示高

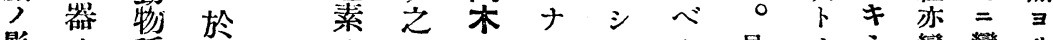

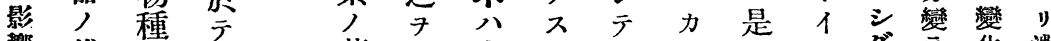

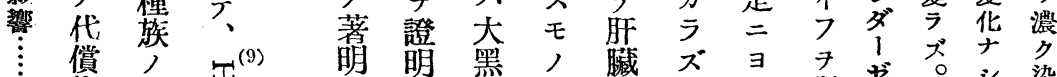

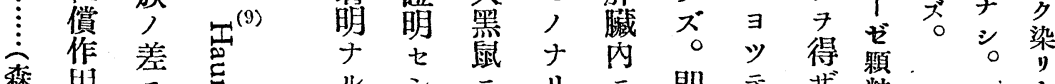

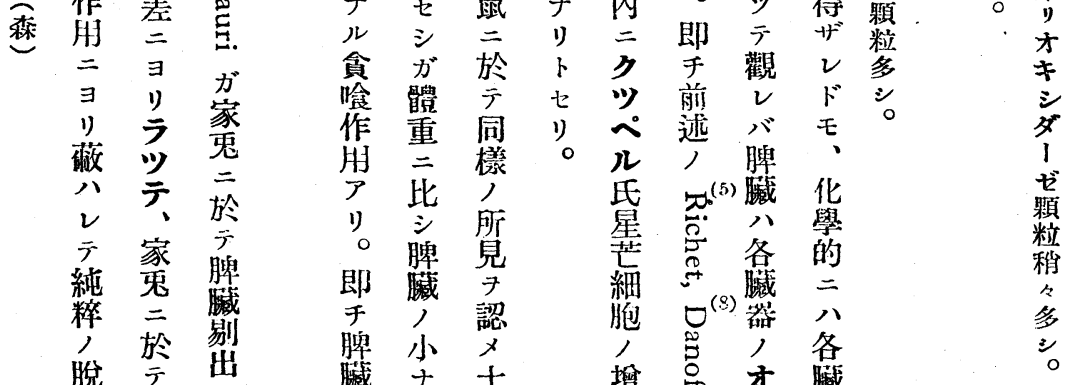

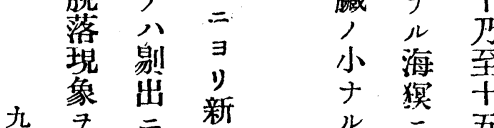

七來三陳水三五

ガ於遇

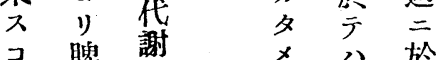

藏筑公公於

困機萑脏, 碱

勤能寻藏盛,

ナ脱認忍 ナ 出

ル落 $x$ 脾り現

二琴 $x^{(n)}$ 藏 $\neq$ 公 $九$ 新, 增

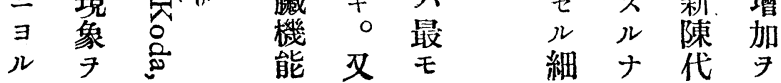




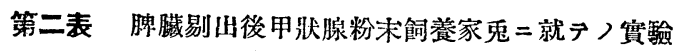

\begin{tabular}{|c|c|c|c|c|c|c|c|c|c|c|c|c|c|c|c|}
\hline \multicolumn{3}{|c|}{ 臟 器 } & \multicolumn{2}{|c|}{ 心 } & 践 & \multicolumn{2}{|r|}{ 督 } & 歲 & \multicolumn{2}{|c|}{ 㬳 } & 噦 & \multicolumn{2}{|c|}{ 碖 } & \multicolumn{2}{|l|}{ 考 } \\
\hline 號 & 家 & 性 & 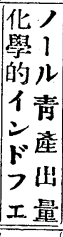 & \begin{tabular}{|c} 
同 \\
增 \\
减 \\
率 \\
$(\%)$ \\
\end{tabular} & \begin{tabular}{|l} 
組 \\
織 \\
學 \\
的
\end{tabular} & 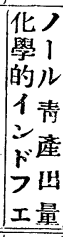 & $\mid \begin{array}{c}\text { 同 } \\
\text { 增 } \\
\text { 减 } \\
\text { 率 } \\
(\%)\end{array}$ & 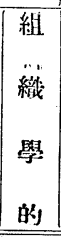 & 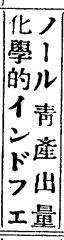 & 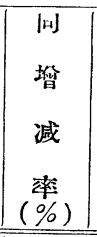 & \begin{tabular}{|c|} 
組 \\
織 \\
學 \\
的
\end{tabular} & $\begin{array}{l}\text { 剔 } \\
\text { 出 } \\
\text { 前 } \\
\text { 體 } \\
\text { 重 }\end{array}$ & $\begin{array}{l}\text { 試 } \\
\text { 驗 } \\
\text { 時 } \\
\text { 體 } \\
\text { 重 } \\
\end{array}$ & $\begin{array}{l}\text { 剔 } \\
\text { 出 } \\
\text { 後 } \\
\text { 䌡 } \\
\text { 過 } \\
\text { 日 } \\
\text { 日數 } \\
\end{array}$ & $\begin{array}{l}\text { 电 } \\
\text { 狀 } \\
\text { 腺 } \\
\text { 給 } \\
\text { 與. } \\
\text { 日 } \\
\text { 數 }\end{array}$ \\
\hline I & 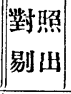 & $\begin{array}{l}\hat{\delta} \\
\hat{f}\end{array}$ & $\begin{array}{r}7.5 \\
12.0 \\
\end{array}$ & +60.0 & +2 & $\begin{array}{l}4.5 \\
6.8\end{array}$ & +51.1 & +2 & $\left|\begin{array}{l}3.7 \\
5.8\end{array}\right|$ & +56.8 & +2 & 2.400 & $\begin{array}{l}1.500 \\
1.500\end{array}$ & 46 & 6 \\
\hline II & $\mid \begin{array}{l}\text { 對照 } \\
\text { 剔估 }\end{array}$ & $\begin{array}{l}\hat{\jmath} \\
\hat{\delta}\end{array}$ & $\begin{array}{r}7.7 \\
10.8\end{array}$ & +40.3 & +2 & $\begin{array}{l}4.6 \\
6.1\end{array}$ & +32.6 & \pm & $\left|\begin{array}{l}3.3 \\
5.7\end{array}\right|$ & +72.7 & +1 & 2.400 & $\begin{array}{l}1.800 \\
1.800\end{array}$ & 47 & 7 \\
\hline UII & $\mid \begin{array}{l}\text { 對照 } \\
\text { 剔山 }\end{array}$ & $\begin{array}{l}\hat{\delta} \\
\hat{\delta}\end{array}$ & $\begin{array}{r}8.0 \\
11.4\end{array}$ & +42.5 & +2 & $\begin{array}{l}4.1 \\
5.8\end{array}$ & +41.5 & +1 & $\begin{array}{l}3.4 \\
5.6\end{array}$ & +64.7 & +1 & 2.100 & $\begin{array}{l}1.900 \\
1.700\end{array}$ & 49 & 7 \\
\hline I V & $\mid \begin{array}{l}\text { 對照 } \\
\text { 剔出 }\end{array}$ & $\begin{array}{l}\hat{\delta} \\
\hat{\delta}\end{array}$ & $\begin{array}{r}7.4 \\
10.5\end{array}$ & +419 & \pm & $\begin{array}{l}5.4 \\
7.2\end{array}$ & +33.3 & +1 & $\begin{array}{l}3.4 \\
5.0\end{array}$ & +47.1 & +2 & 2.100 & $\begin{array}{l}2.000 \\
1.700\end{array}$ & 50 & 7 \\
\hline$V$ & $\mid \begin{array}{l}\text { 對照 } \\
\text { 剔泏 }\end{array}$ & 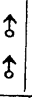 & $\begin{array}{r}8.2 \\
10.1 \\
\end{array}$ & +23.2 & +1 & \begin{tabular}{|l|}
4.2 \\
5.5
\end{tabular} & +31.0 & +1 & $\begin{array}{l}3.0 \\
5.3\end{array}$ & +76.7 & +1 & 2.000 & $\begin{array}{l}1.900 \\
1.900\end{array}$ & 28 & 7 \\
\hline & $\mid \begin{array}{l}\text { 對照 } \\
\text { 剔绌 }\end{array}$ & & $\begin{array}{r}7.8 \\
11.0\end{array}$ & +41.2 & & $\begin{array}{l}4.6 \\
6.3 \\
\end{array}$ & +37.7 & & $\begin{array}{l}3.4 \\
5.5\end{array}$ & +63.1 & & & & & \\
\hline
\end{tabular}

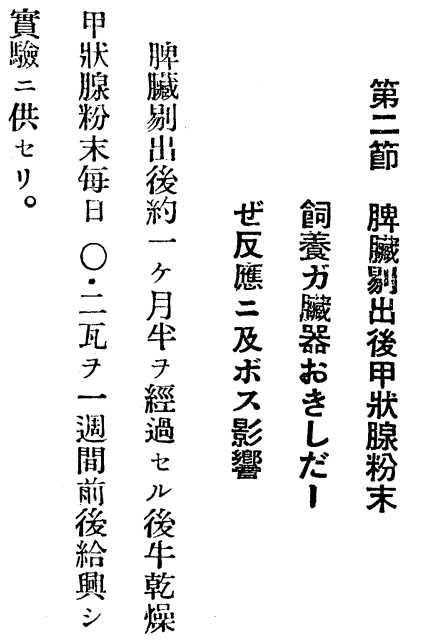

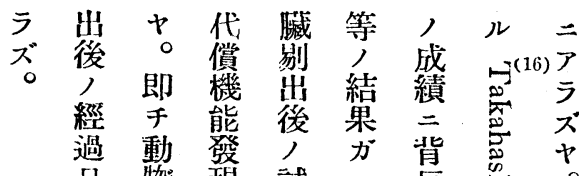

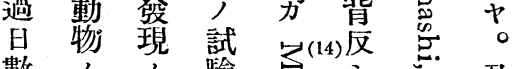

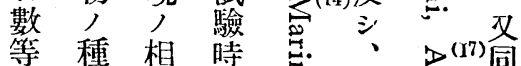
尹 類 違 期 。 考疗三人, 犬 虑 實 歸 差夫 於等 物 光

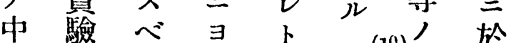
$==キ リ-\mathbb{1}^{\left(\mathbf{1}^{(1)}\right.}$ 所 置 供

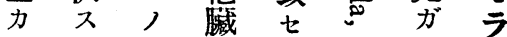

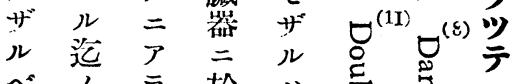

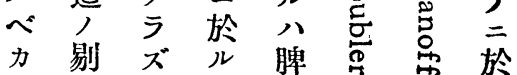




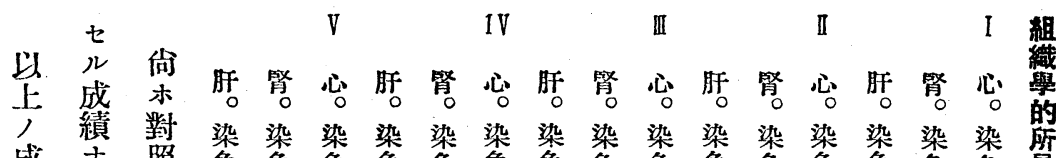
諸成与照色色色色色色色色色色色色色色色啠

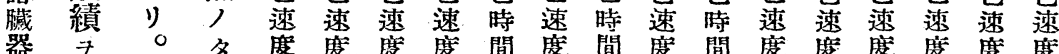
～第 $x$ 早早早極早八早早早速速速

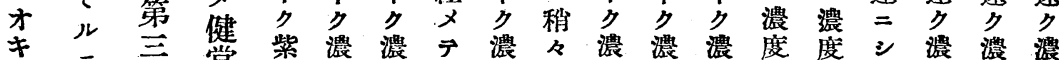

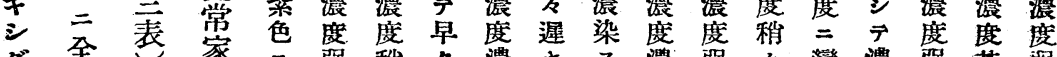

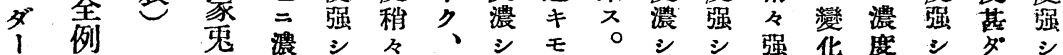

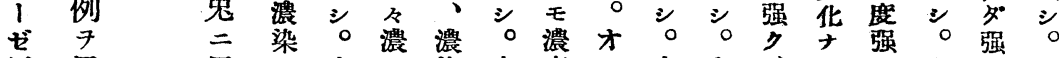

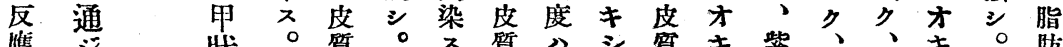

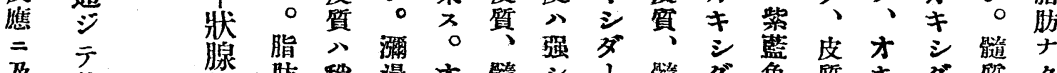

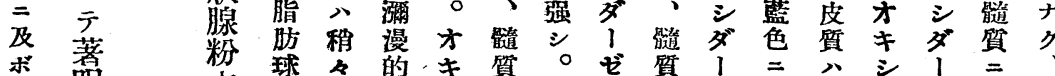

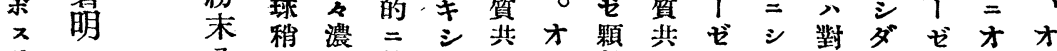
脾二 タ タク染ダニキ粒三顆テ照了顆キキ

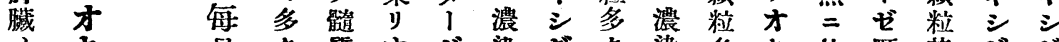

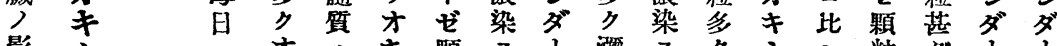

$\bigcirc$ キ 極

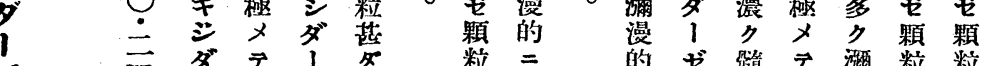

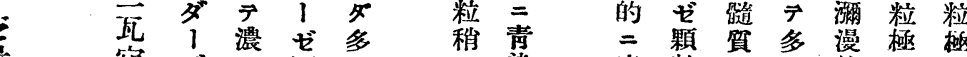

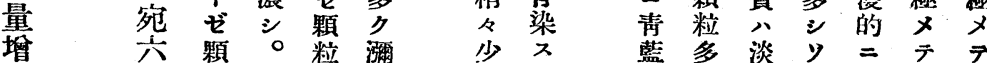

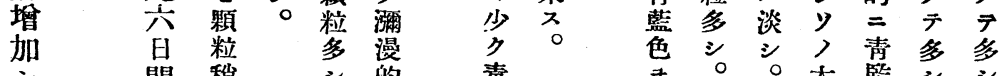

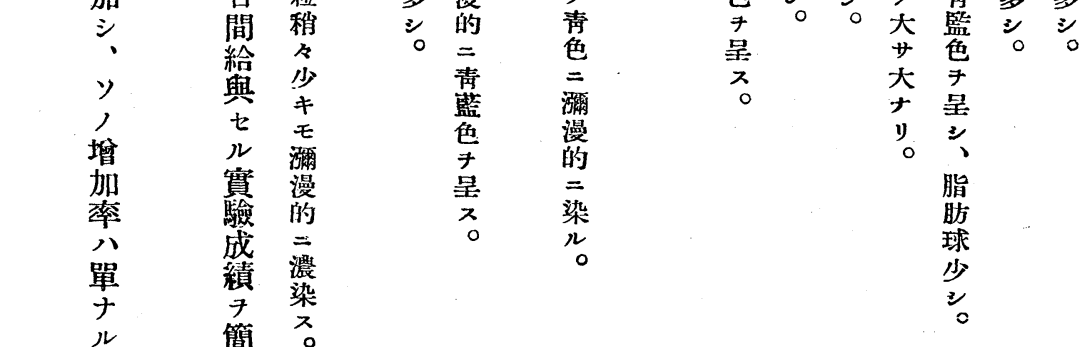

甲

甲 單

古腺云揭

末分

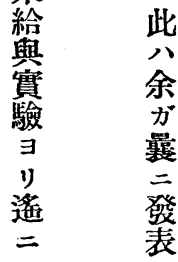


最 第 事

モ - 實

影二

隌 全 認

七 部

ラ 所 タ

ル 臟 リ

八二

肝 入所

蔵 入解

$ナ$ ○剖

亏 即 學

ザ 手的

儿脾 二

べ臟 考

力 二 祭

ラ $ヨ$ ス

ズリ レ

○生 バ

余運 脾

七 箴

得 三

夕 $v$ 門

ル夕脈

成儿采

績 小 統

八此中

此 モ

, ン介

間 八在

ノ最 シ

渻 モ 排

息 强 泄

丹ク 管

暗 所

裏 臟有

雃 襲 ス

ス 警

ル ス

モ $\mathrm{c}$

ノ從 リ

ナ方出

リ脾 ジ

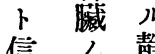

物力學說卜病 千无

ズ 變脈 筫

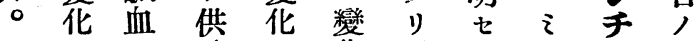

二八給 化。ラル氏

$\exists$ 先

リジル ズ 來驗シ シ 所病方 八二缄脾肝腫化婜 羿 $\exists$ 剔臟淢・7 密

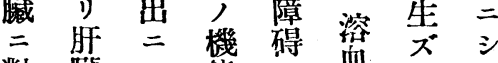

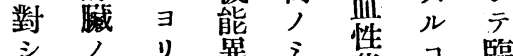

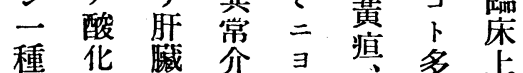
二在り シ 三 刺還組 ス來白。於 戟元織卜ル血即テ
第三表 甲狀腺粉末飼養家鬼二於テノ實驗

\begin{tabular}{|c|c|c|c|c|c|c|}
\hline 臟 器 & 心 & 噦 & 筒 & 獩 & 肝 & 践 \\
\hline 番 & 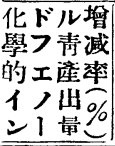 & $\begin{array}{l}\text { 組 } \\
\text { 織 } \\
\text { 學 } \\
\text { 的 }\end{array}$ & 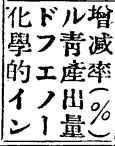 & $\begin{array}{l}\text { 組 } \\
\text { 織 } \\
\text { 學 } \\
\text { 的 }\end{array}$ & 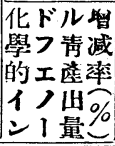 & $\begin{array}{l}\text { 組 } \\
\text { 織 } \\
\text { 學 } \\
\text { 的 } \\
\end{array}$ \\
\hline I & +10.6 & +1 & \pm 0 & +2 & +23.3 & +1 \\
\hline II & +31.1 & \pm & +21.1 & +1 & +7.0 & +1 \\
\hline III & +16.0 & +1 & +37.5 & +2 & +35.5 & +1 \\
\hline IV & +35.4 & +1 & +16.7 & +2 & -5.0 & $t_{1}$ \\
\hline V & +56.8 & +1 & +18.9 & +1 & +12.5 & +1 \\
\hline 本 均 & +24.5 & & +19.9 & & +13.1 & \\
\hline
\end{tabular}

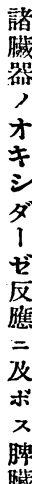

歲

影

響

味テ同高

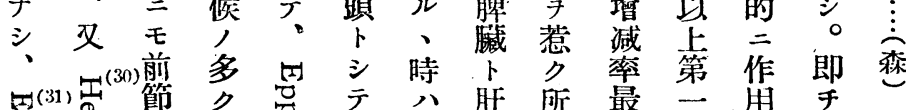

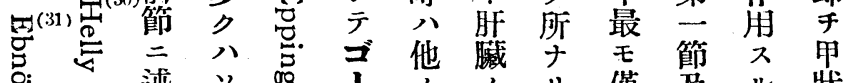
号, 述り

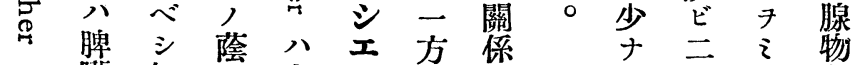
シ $>0$ 給 胿 害 而 舆 藏跐 シ テ ノ テ フ 管 ヨ堆 因 加 リ 加子 率從 率上 萊了脾 却 余 最藏 少壬剔 最行著 出 モ 大 シ キ ナ諸 八因 ル種朋子 八, 藏卜 吾 實ナガ 人驗り互 興於 共
九 公 
第四表 脾㖪及ビ甲狀腺剔出家鬼二就テノ實驗

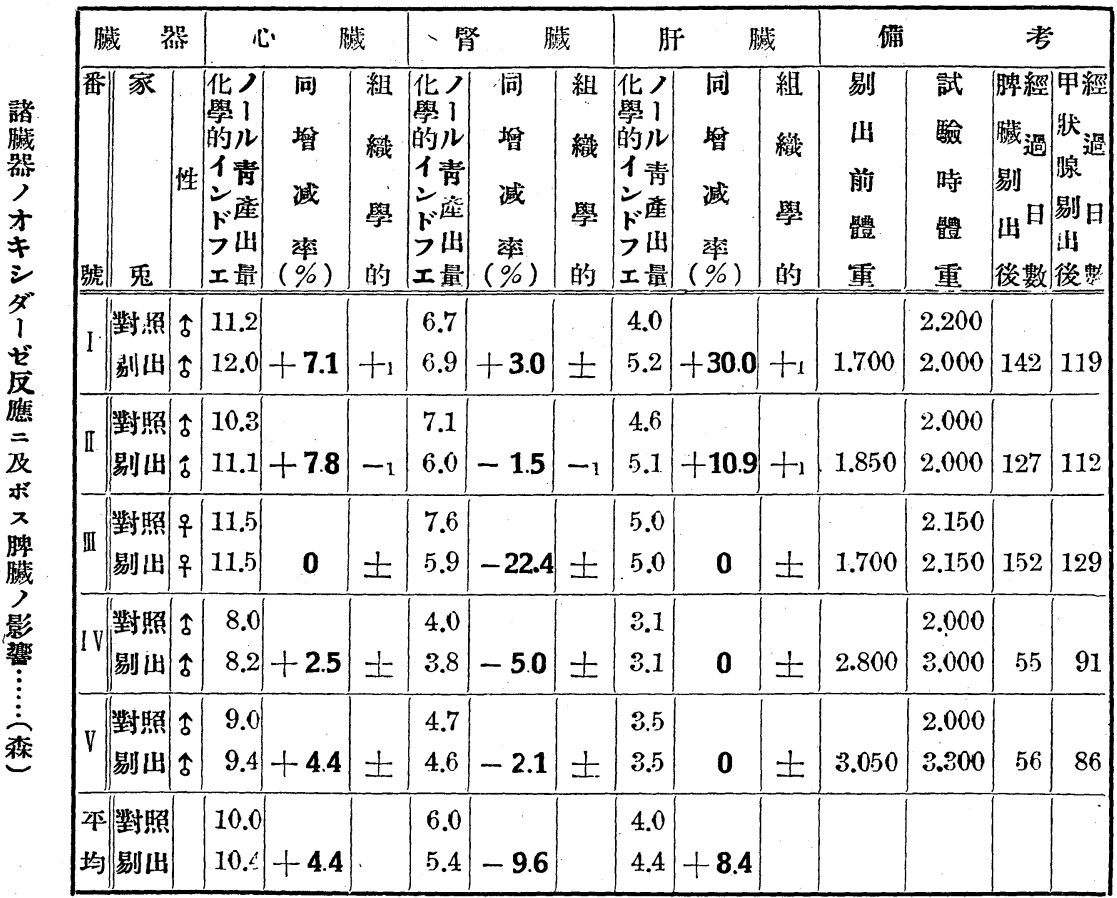

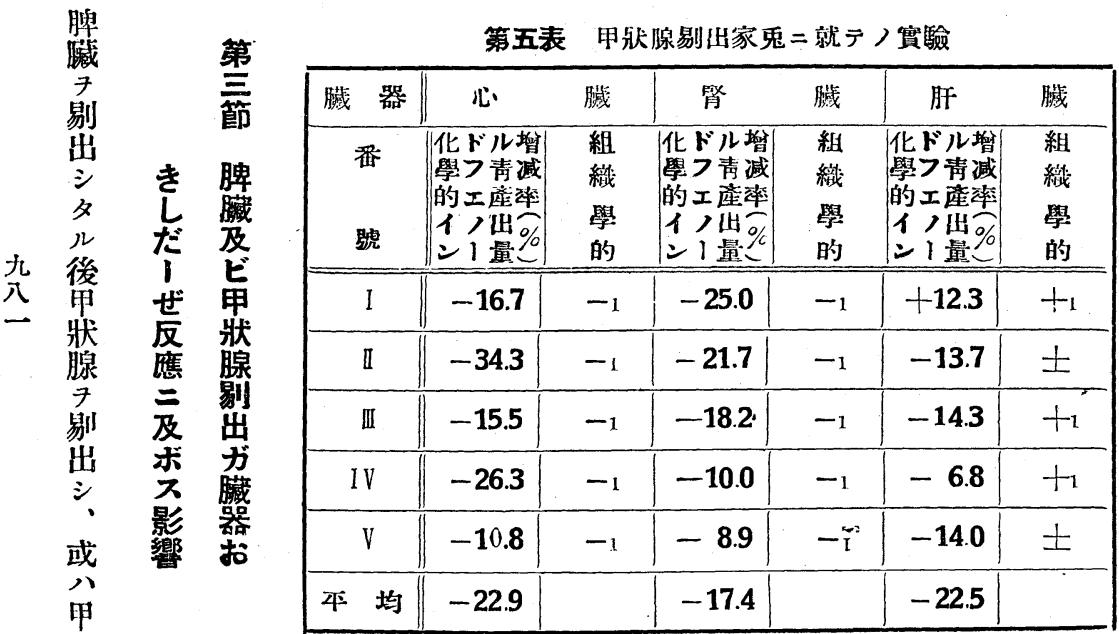




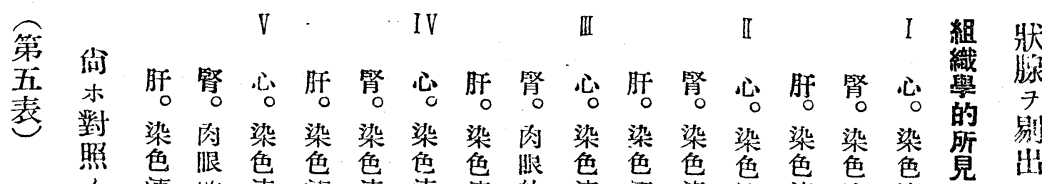

速的速速速速速的速速速速速速速膊

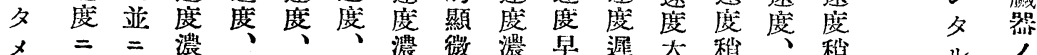

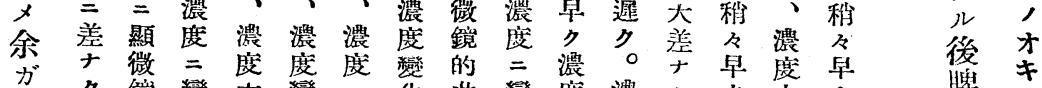

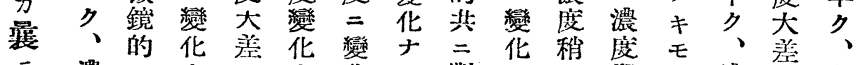

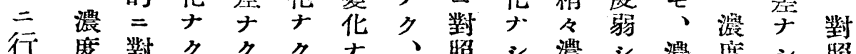

七 秒照毒紫、シオ

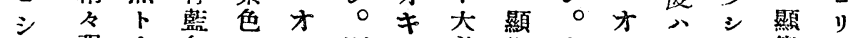

甲强大色

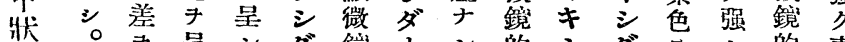

腺 脂圽

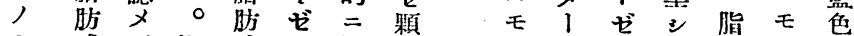

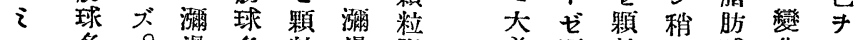

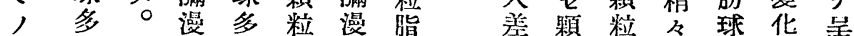

剔ク的名公的肪粒少淡父け

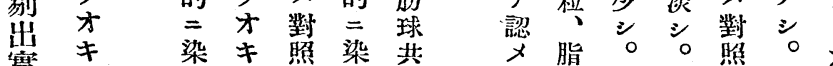

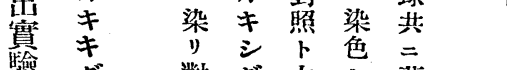

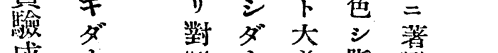

成蔶ざ 照

尹 顆 此顆 シ 球 シ
簢

嘽煘脂少 キ

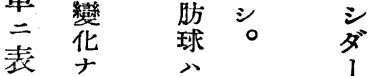

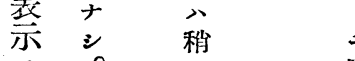

ス 々 顆

剔

少粒

II

後

䄪

$\vec{t}$

日

䋔

ズ脂

。昹

共

$=$

脕き

藏 ダ

71

剔 ゼ

出反

シ 應

云 文 


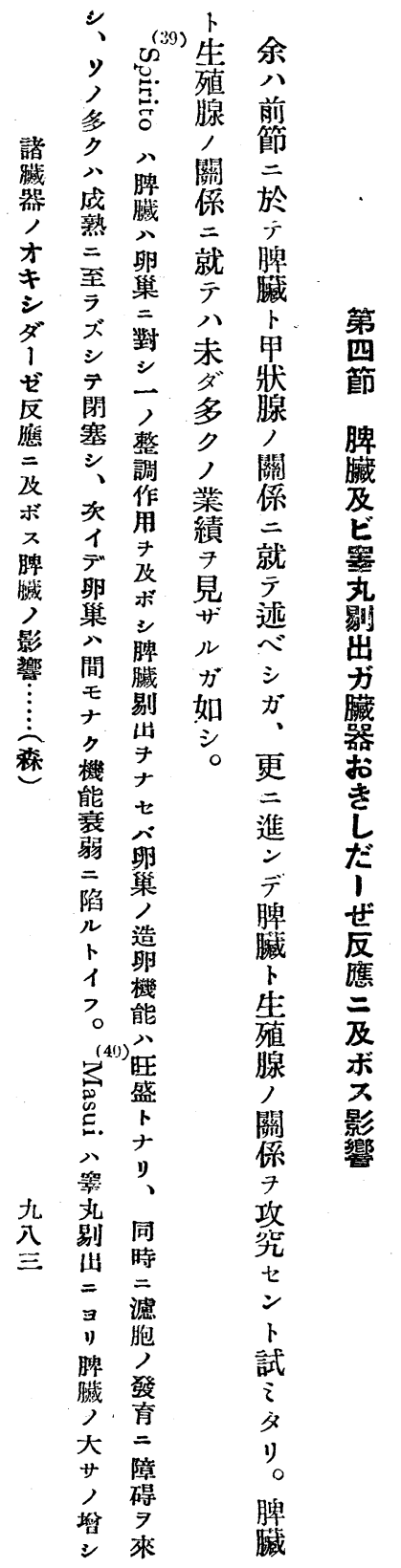

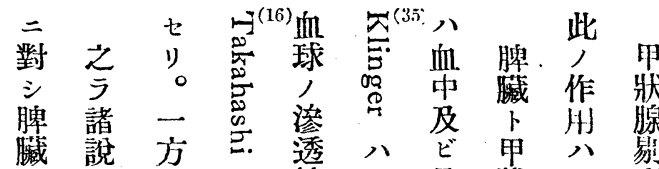

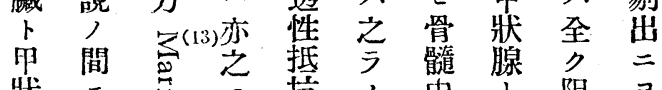
狀二可抗, 中阻 $\exists$ 腺 $ア$ 賛二業, , 止》

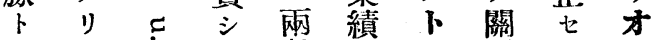
ガラ、者二、係亏手 互占述最拮對 ジ就テ多 捛, 莺 抗第吉禹性, 含八毛 的一八䓃 7 蒀有始 $シ$ 量

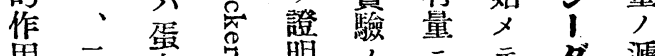

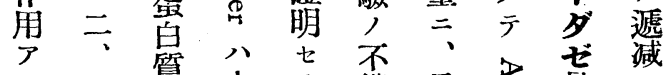

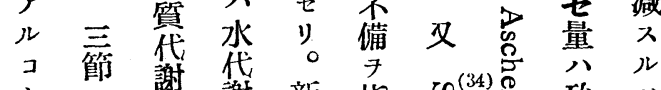
卜八謝謝新指 $\underbrace{(34)} \stackrel{9}{\leftrightarrows}$ 殆八

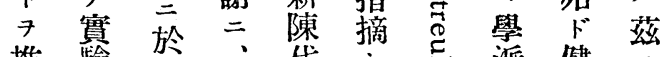

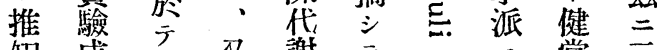
知成嗰圣謝 $テ=$ 常示 七績何我方駁八ヨ價 シ八拮教面論酸り二戍

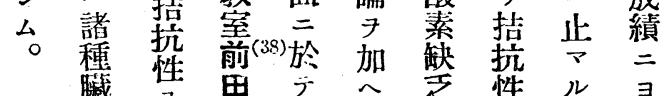

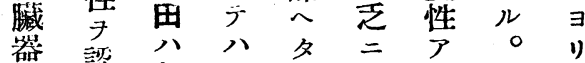
兴認各 $\mathbb{T}^{(9)}$ り對り明

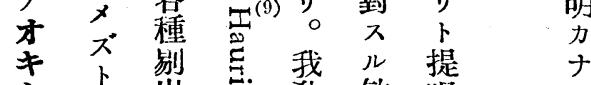

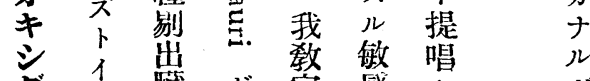
ダフ藏㬝䇪感 七 ガ

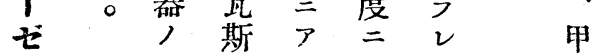
反桼帒少、於实狀 應 斯 謝 .5 宁 $\uplus^{(32)}$ 腺 延 謝雨 祝(26)霫吕向 1 二者八?八時 テ需, 血拈 血.

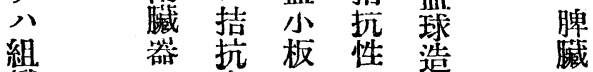
織 J作, 齐成录 的拮用產認 二(3:3) 剔 新执 7 生 $x \overbrace{}^{(3.3)}$ 出 陳性認三立节不

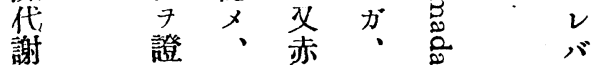


IV II $\quad$ II $\quad$ I

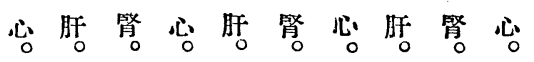

染 染 染染染 染 染染 染 染

色色速色色色速色色速速色速

度度度度度度度度度度

稍差漂稍大、大變稍稍

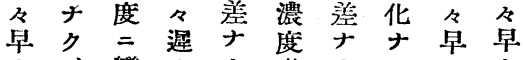

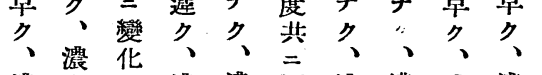

濃度ナ濃濃戀 濃濃濃濃

传僅妾度度化度度度度

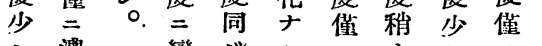

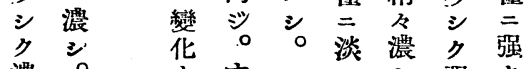

浱范华年

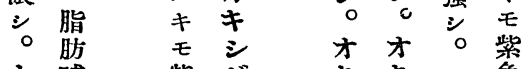

オ球紫名年キ色

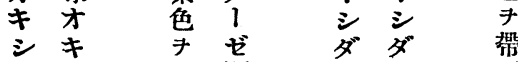

ダシ 觜顆

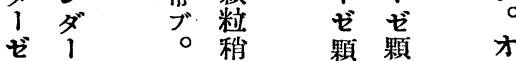

顆ぜ粒粒 オ

粒顆

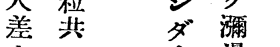

ナ $=1$ 漫

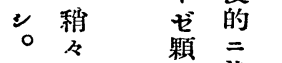

多 粒染 差毒 粒

沙色染染

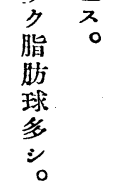

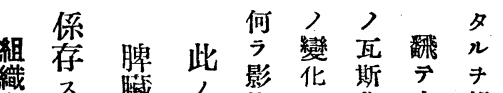

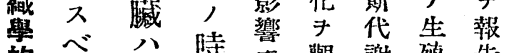
的 分時萃觀謝殖告

所キ剔二 党祭留腺七諸 出當卜言降方り臟 $\circ=\emptyset 1$ 以 7 新 0 器 脾 $\exists$ ( $^{(46)}$ 七 $テ$ 報陳 臟り安、去沙代 剔才田尔泣萟 、謝 出 キ 少营 時

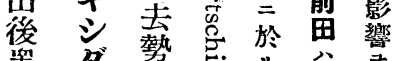

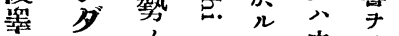
罢 グ 剔量 器三機動 出了哥替能物口

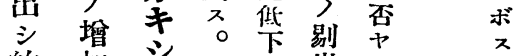
約加

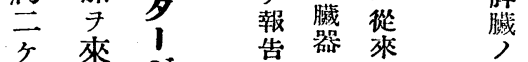
月 流艺諸影 丹文皮当於種

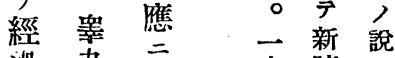
過丸文方陳买 七剔ボ ル 剔 ボ モ出 變 二 $三$ 化 就り 检 テソ 檢 實人明 的少力

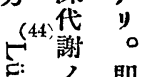
壱. 减 即

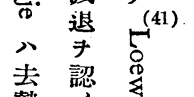

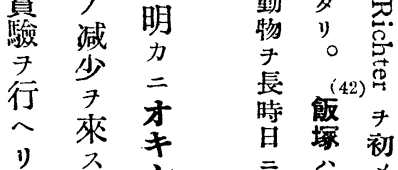

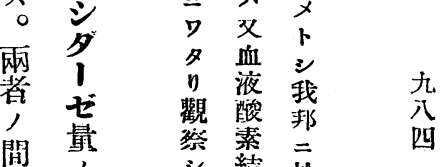
果卡音結 於 果降體吕 ${ }^{\text {並 }}$

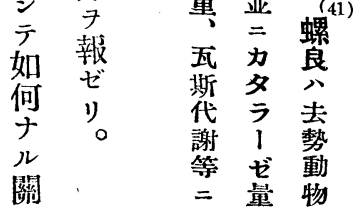




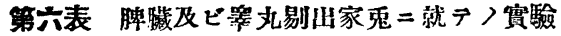

\begin{tabular}{|c|c|c|c|c|c|c|c|c|c|c|c|c|c|c|c|}
\hline \multicolumn{3}{|c|}{ 獩 器 } & \multicolumn{2}{|c|}{ 心 } & 睵 & \multicolumn{2}{|c|}{ 筒 } & 臟 & \multicolumn{2}{|c|}{ 肝 } & 臟 & \multicolumn{2}{|c|}{ 碏 } & \multicolumn{2}{|l|}{ 考 } \\
\hline 番 & 家 & 泩 & 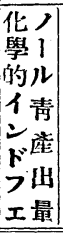 & \begin{tabular}{|c|} 
同 \\
增 \\
减 \\
率 \\
$(\%)$ \\
\end{tabular} & $\begin{array}{l}\text { 組 } \\
\text { 織 } \\
\text { 學 } \\
\text { 的 }\end{array}$ & 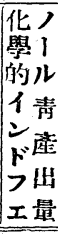 & $\begin{array}{c}\text { 同 } \\
\text { 增 } \\
\text { 减 } \\
\text { 新 } \\
(\%) \\
\end{array}$ & $\begin{array}{l}\text { 組 } \\
\text { 織 } \\
\text { 學 } \\
\text { 的 }\end{array}$ & 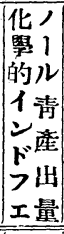 & \begin{tabular}{|c|} 
同 \\
增 \\
减 \\
率 \\
$(\%)$ \\
\end{tabular} & $\begin{array}{l}\text { 組 } \\
\text { 織 } \\
\text { 學 } \\
\text { 的 } \\
\end{array}$ & $\begin{array}{l}\text { 剔 } \\
\text { 出 } \\
\text { 前 } \\
\text { 體 } \\
\text { 重 } \\
\end{array}$ & $\begin{array}{l}\text { 試 } \\
\text { 驗 } \\
\text { 時 } \\
\text { 體 } \\
\text { 重 } \\
\end{array}$ & 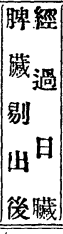 & $\begin{array}{l}\text { 睪經 } \\
\text { 丸過 } \\
\text { 剔 } \\
\text { 日 } \\
\text { 出 } \\
\text { 後數 } \\
\end{array}$ \\
\hline I & $\mid \begin{array}{l}\text { 對照 } \\
\text { 剔沾 }\end{array}$ & $\left|\begin{array}{l}\hat{\delta} \\
\hat{\delta}\end{array}\right|$ & $\begin{array}{l}7.6 \\
8.2\end{array}$ & +7.9 & \pm & $\begin{array}{l}4.5 \\
4.6\end{array}$ & +2.2 & +1 & $\begin{array}{l}3.0 \\
3.7\end{array}$ & +23.3 & \pm & 1.900 & $\begin{array}{l}2.200 \\
2.200\end{array}$ & 57 & 50 \\
\hline II & $\mid \begin{array}{l}\text { 對照 } \\
\text { 剔! }\end{array}$ & $\begin{array}{l}\hat{\delta} \\
\hat{\delta}\end{array}$ & $\begin{array}{l}8.9 \\
8.2\end{array}$ & -7.9 & \pm & $\begin{array}{l}4.1 \\
5.3\end{array}$ & +29.3 & \pm & $\begin{array}{l}3.4 \\
3.5\end{array}$ & +2.9 & \pm & 1.850 & $\begin{array}{l}2.450 \\
2.350\end{array}$ & 62 & 53 \\
\hline III & 㭩照 & $\begin{array}{l}\hat{\delta} \\
\hat{\delta}\end{array}$ & $\begin{array}{l}7.5 \\
7.6\end{array}$ & +1.3 & \pm & $\begin{array}{l}4.1 \\
5.0\end{array}$ & +22.0 & \pm & $\begin{array}{l}3.0 \\
3.0\end{array}$ & 0 & \pm & 1.850 & $\begin{array}{l}2.000 \\
2.000\end{array}$ & 64 & 55 \\
\hline IV & $\left|\begin{array}{l}\text { 對照 } \\
\text { 剔出 }\end{array}\right|$ & $\left|\begin{array}{l}\hat{\delta} \\
\hat{\delta}\end{array}\right|$ & $\begin{array}{l}7.9 \\
7.8\end{array}$ & -1.3 & \pm & $\begin{array}{l}3.2 \\
3.2\end{array}$ & 0 & \pm & $\begin{array}{l}2.5 \\
2.5\end{array}$ & 0 & \pm & 2.000 & $\begin{array}{l}2.250 \\
2.100\end{array}$ & 88 & 53 \\
\hline V & $\left|\begin{array}{l}\text { 對照 } \\
\text { 剔出 }\end{array}\right|$ & $\left|\begin{array}{l}\hat{\delta} \\
\hat{\delta}\end{array}\right|$ & $\begin{array}{l}7.8 \\
7.6\end{array} \mid$ & -2.6 & \pm & $\begin{array}{l}4.2 \\
4.1\end{array}$ & -24 & \pm & $\begin{array}{l}3.8 \\
3.6\end{array}$ & -5.3 & \pm & 2.200 & $\begin{array}{l}2.200 \\
2.200\end{array}$ & 52 & 24 \\
\hline 4 & $\left|\begin{array}{l}\text { 龊照 } \\
\text { 剔仙 }\end{array}\right|$ & & $\begin{array}{l}7.9 \\
7.9\end{array}$ & -0.8 & & $\begin{array}{l}4.0 \\
4.4\end{array}$ & +10.4 & & $\begin{array}{l}3.1 \\
3.3\end{array}$ & +6.1 & & & & & \\
\hline
\end{tabular}

上全降犯少ナ示

ル少剔以さ゚る佮

于阻等出上等。等

歨丸 $九$ 第第 ${ }^{(45)}$ 剔 對

ル七ト

亏同り表表

2 時 起

$\bar{\tau}=ル$ 第

九 健脾 べ菁

五

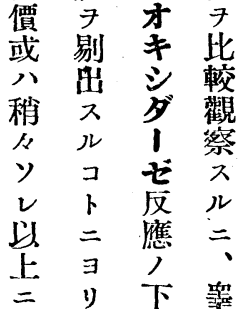

氏 六夕

論古羙

变获

中至尚

1日,

引 7 剔

用經出

七過 實

ル

ナ

䏦腎出 䏦 督

染 染 染染濃 染染

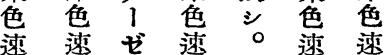

毁度顆度才度度

濃濃、粒稍 $キ$ 二稍

度度對々心美々

二=照早多早

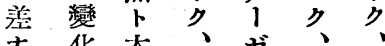

ナ华菣濃顆甍濃

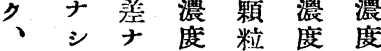

顯。ク浱對八稍

微桷 シ 照紫々

鑜 漫。色濃

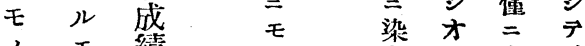

ノモ 續

戀色き多秽 


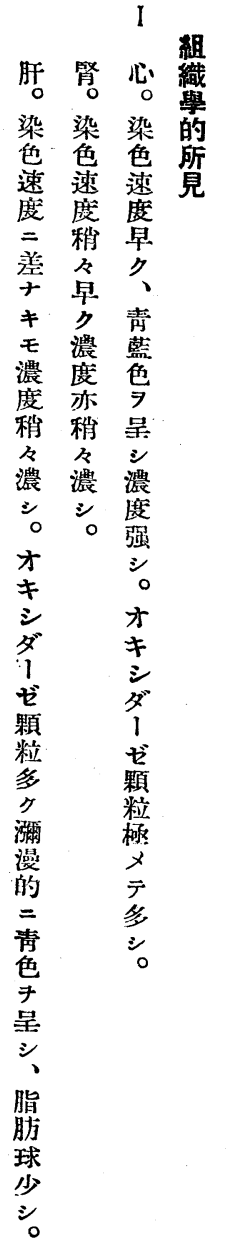

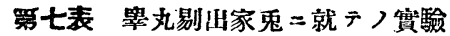

\begin{tabular}{|c|c|c|c|c|c|c|}
\hline 歲 器 & 心 & 臟 & 監 & 臟 & 肝 & 臟 \\
\hline 番 & 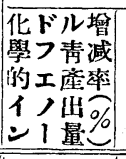 & $\begin{array}{l}\text { 組 } \\
\text { 蟣 } \\
\text { 學 } \\
\text { 的 }\end{array}$ & 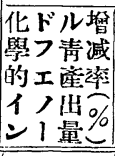 & $\begin{array}{l}\text { 組 } \\
\text { 織 } \\
\text { 學 } \\
\text { 的 } \\
\end{array}$ & 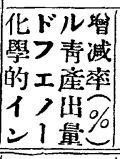 & $\begin{array}{l}\text { 組 } \\
\text { 織 } \\
\text { 學 } \\
\text { 的 } \\
\end{array}$ \\
\hline I & -29.1 & -1 & -14.5 & -1 & +243 & -1 \\
\hline II & -27.3 & -1 & -9.1 & -1 & 0 & \pm \\
\hline III & -0.8 & -1 & -3.9 & -1 & -4.4 & \pm \\
\hline IV & -36.8 & -1 & -31.0 & -1 & -25.0 & $-I$ \\
\hline V & -41.0 & \pm & +3.7 & \pm & +11.8 & \pm \\
\hline 平均 & -26.6 & & -123 & & -0.4 & \\
\hline
\end{tabular}

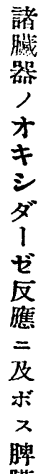

戯

宛 才 粉素二常 品

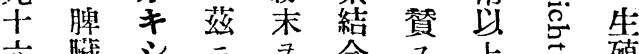

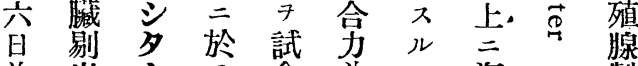

前出 1 食並乇迄八製

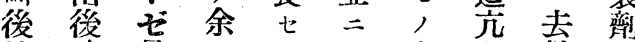

給 約量

與五厂脾 $x$ タ シ t二成

シ十變 臓 著

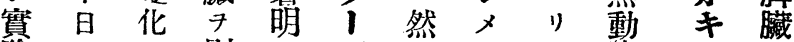

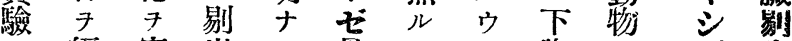

二經究出儿量二小降ノ多出

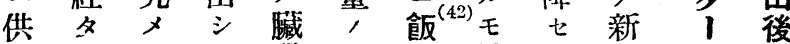

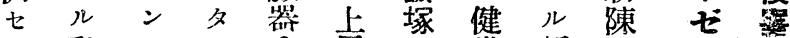

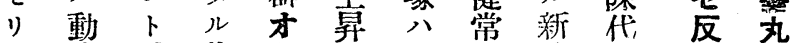

○物試後 $\neq$ ス 正動陳謝應粉

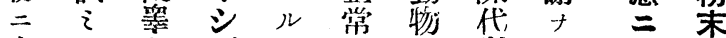

牛夕丸多 7 動二謝昆及飼

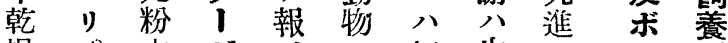

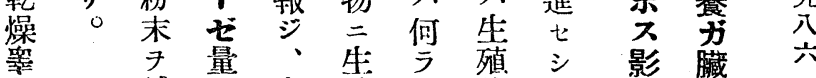

丸試, 安(4)殖影腺メ響器

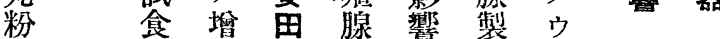

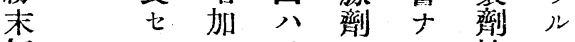

每 シ 7 又 7 給ヤ

日 x 證乾與卜與染

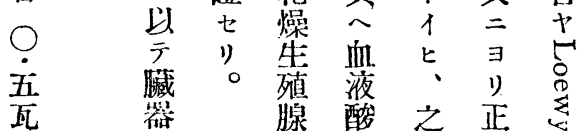




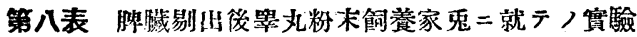

\begin{tabular}{|c|c|c|c|c|c|c|c|c|c|c|c|c|c|c|}
\hline \multicolumn{2}{|c|}{ 葴 哭 } & \multicolumn{3}{|c|}{ 心 戨 } & \multicolumn{3}{|c|}{ 腎 歲 } & \multicolumn{3}{|c|}{ 肝 裁 } & \multicolumn{2}{|c|}{ 踊 } & \multicolumn{2}{|l|}{ 洘 } \\
\hline 號 恶 & 性 & 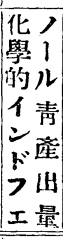 & \begin{tabular}{|c|} 
同 \\
增 \\
减 \\
率 \\
$(\%)$ \\
\end{tabular} & \begin{tabular}{|l} 
組 \\
織 \\
學 \\
的
\end{tabular} & 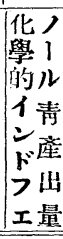 & 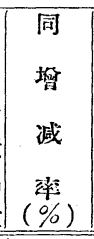 & $\begin{array}{l}\text { 組 } \\
\text { 織 } \\
\text { 學 } \\
\text { 的 } \\
\end{array}$ & 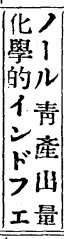 & \begin{tabular}{|c|} 
同 \\
增 \\
减 \\
率 \\
$(\%)$ \\
\end{tabular} & $\begin{array}{l}\text { 組 } \\
\text { 織 } \\
\text { 學 } \\
\text { 的 }\end{array}$ & $\begin{array}{l}\text { 剔 } \\
\text { 出 } \\
\text { 前 } \\
\text { 體 } \\
\text { 重 } \\
\end{array}$ & $\begin{array}{l}\text { 試 } \\
\text { 驗 } \\
\text { 時 } \\
\text { 體 } \\
\text { 重 } \\
\end{array}$ & $\begin{array}{l}\text { 剔 } \\
\text { 出 } \\
\text { 後 } \\
\text { 經 } \\
\text { 過 } \\
\text { 日 } \\
\text { 數 } \\
\end{array}$ & $\begin{array}{l}\text { 睪 } \\
\text { 品 } \\
\text { 粉 } \\
\text { 梠 } \\
\text { 給 } \\
\text { 興 } \\
\text { 日 } \\
\text { 數 } \\
\end{array}$ \\
\hline I | & $\left|\begin{array}{l}\mid \\
\hat{\delta}\end{array}\right|$ & $\begin{array}{r}7.6 \\
11.9\end{array}$ & +56.5 & +1 & $\begin{array}{l}4.5 \\
6.0\end{array}$ & +33.3 & +1 & $\begin{array}{l}3.0 \\
4.1\end{array}$ & +36.7 & +1 & 1.900 & $\begin{array}{l}2.200 \\
2.200\end{array}$ & 46 & 15 \\
\hline II $\left\{\begin{array}{l}\text { 對照 } \\
\text { 剔出 }\end{array}\right.$ & $\begin{array}{l}\hat{\delta} \\
\hat{\delta} \\
\hat{\delta}\end{array}$ & $\begin{array}{r}8.9 \\
11.2\end{array}$ & +25.8 & +1 & $\begin{array}{l}4.1 \\
5.6\end{array}$ & +36.3 & +1 & $\begin{array}{l}3.4 \\
4.1\end{array}$ & +20.6 & +1 & 2.200 & $\begin{array}{l}2.450 \\
2.300\end{array}$ & 48 & 18 \\
\hline III 對照 & $\left|\begin{array}{l}\hat{\delta} \\
\hat{\delta}\end{array}\right|$ & \begin{tabular}{|r|}
7.5 \\
10.8 \\
\end{tabular} & +44.0 & +1 & $\begin{array}{l}4.1 \\
5.6\end{array}$ & +36.6 & +1 & $\begin{array}{l}3.0 \\
3.5\end{array}$ & +16.7 & +1 & 2.000 & $\begin{array}{l}2.000 \\
2.100\end{array}$ & 39 & 17 \\
\hline IV $\| \begin{array}{l}\text { 對照 } \\
\text { 剔出 }\end{array}$ & $\mid \begin{array}{l}\hat{\delta} \\
\hat{\delta}\end{array}$ & $\begin{array}{r}7.9 \\
10.2\end{array}$ & +29.1 & \pm & $\begin{array}{l}3.9 \\
3.9\end{array}$ & +27.9 & \pm & $\begin{array}{l}2.5 \\
2.7\end{array}$ & +8.0 & \pm & 1.900 & $\begin{array}{l}2.250 \\
2.200\end{array}$ & 53 & 15 \\
\hline$V \mid \begin{array}{l}\text { 㭩照 } \\
\text { 剔泏 }\end{array}$ & \begin{tabular}{|l|}
$\hat{\delta}$ \\
$\hat{\delta}$
\end{tabular} & $\begin{array}{l}7.8 \\
9.2\end{array}$ & +17.9 & +1 & $\begin{array}{l}4.2 \\
5.2\end{array}$ & +23.8 & +1 & $\begin{array}{l}3.8 \\
3.8\end{array}$ & 0 & +1 & 2.000 & $\begin{array}{l}2.200 \\
2.200\end{array}$ & 41 & 16 \\
\hline 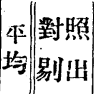 & & $\begin{array}{r}7.9 \\
10.7\end{array}$ & +34.3 & & $\begin{array}{l}4.0 \\
5.3\end{array}$ & +30.8 & & $\begin{array}{l}3.1 \\
3.6\end{array}$ & +19.0 & & & & & \\
\hline
\end{tabular}

V

心。䏦 腎

1染 1染染 三

ゼ色ゼ色色名

顆速顆速速 1

粒

多

九 :

公

圊美粱含粒
IV

心 䏦 督

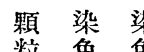

踥急速

度度

○稍 變

化

早

藍学、品早

色。漉

浱喥稍莎。

度濃

强淡 齐。

今

ॠ $才$

キ

桨弪
浱

源

强度

ク、稍

才搌

妾。

多

オ

度
强

シ

キ

ゼ
III

心 腰

キ染名染三色

分速色束

1 度 顆度

ゼ早 粒。

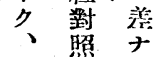

搌照 ま

度多漕

多度

青 脂 僅

藍 肪 =

色 球 强

是尖 。

旺 齐 才

ז

オ
II

督吢

皮染 I 染

色色色

㗪䢞顆速

算早對琹

共キ照

$=$ E

濃瀑、、、

”度多摆

、大 度

才洷、稍

キナ脂及

シ シ 肪溜

多。珴 シ

1 顯 $ナ$

代 微 シ

顆微。キ

粒 的 


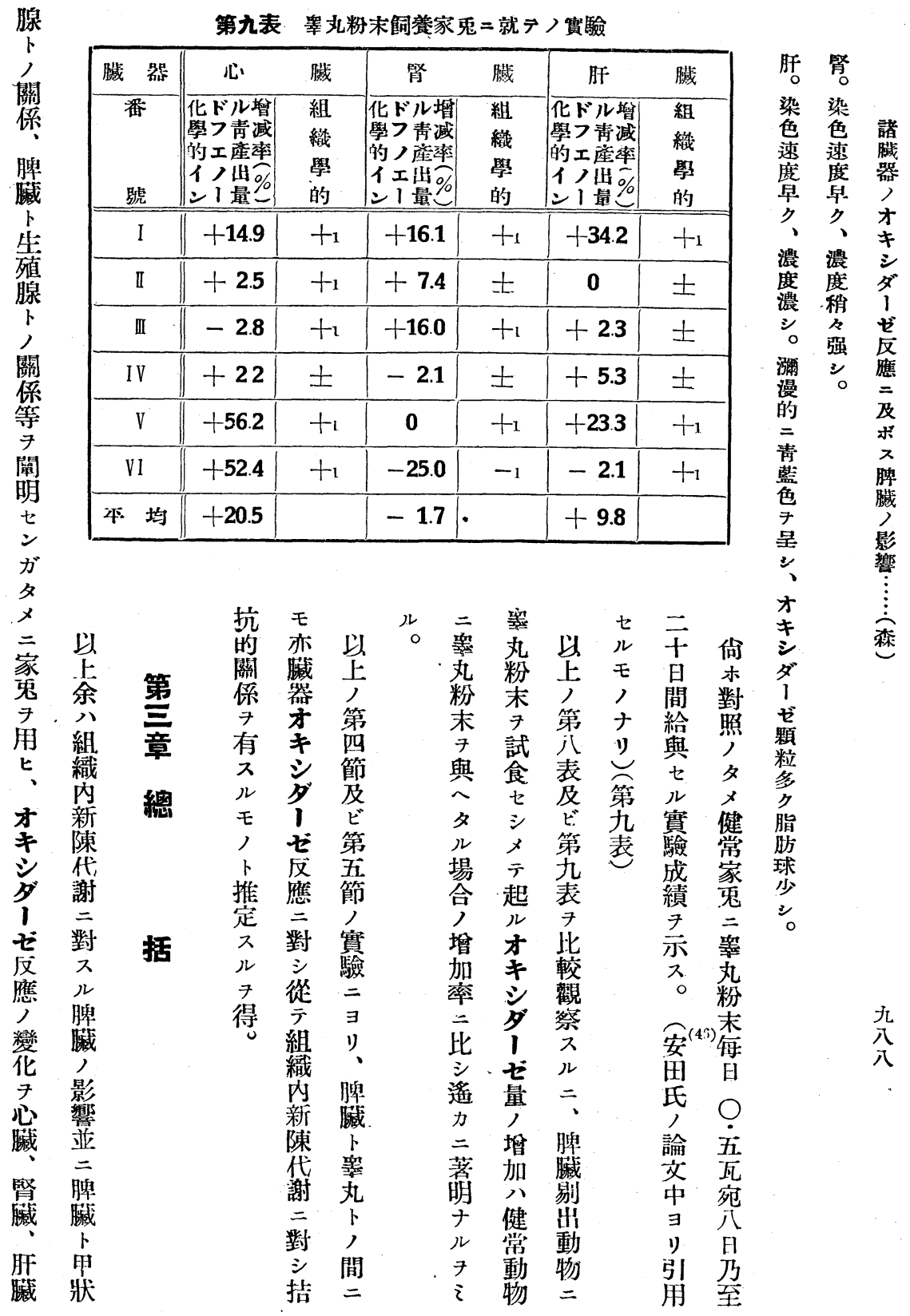




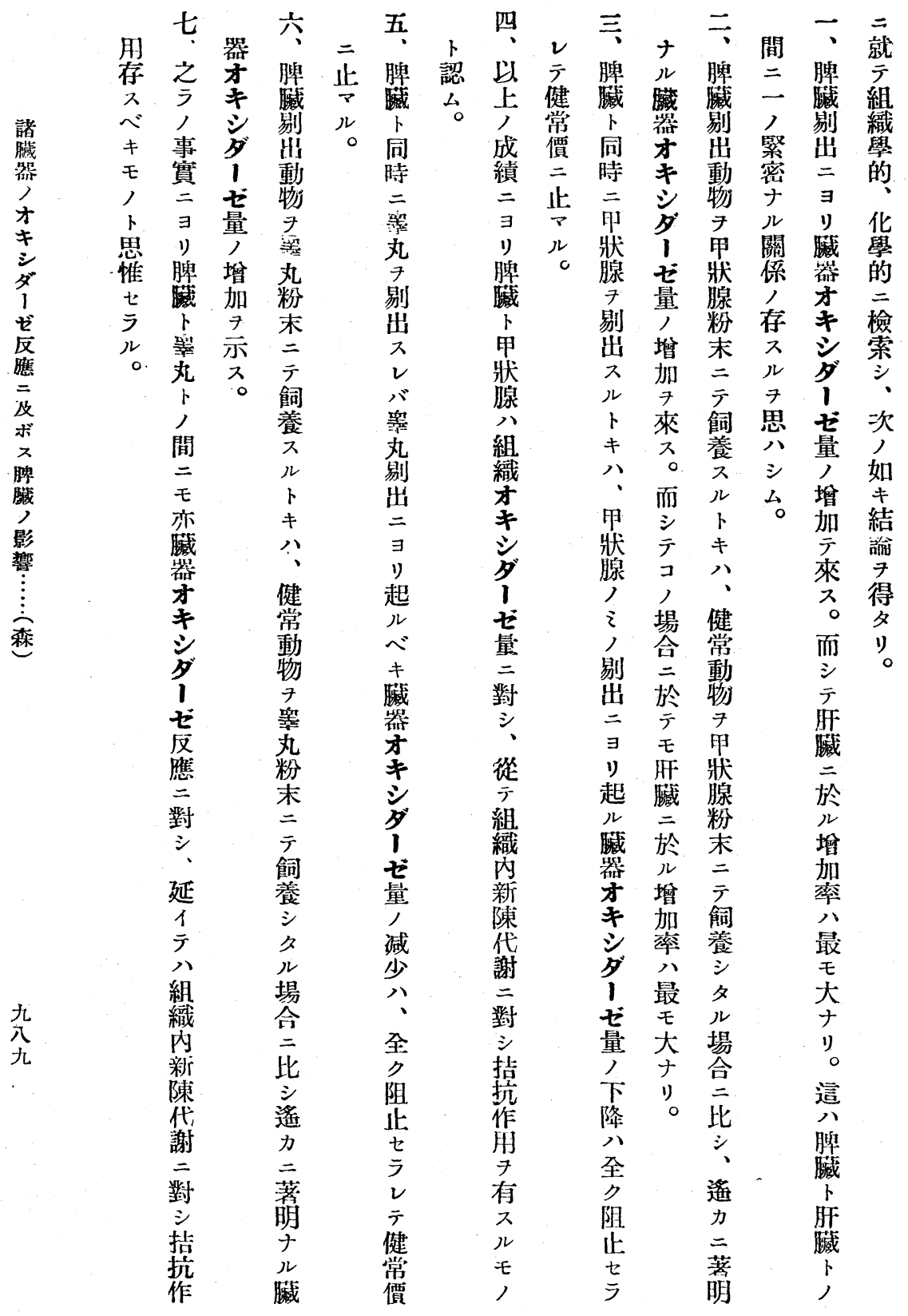


ص W

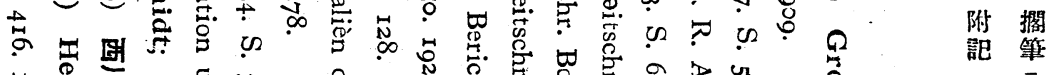

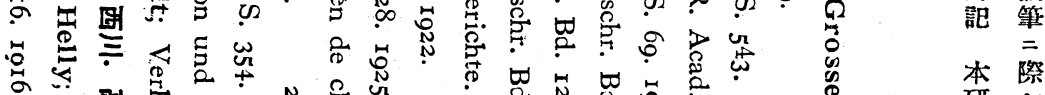

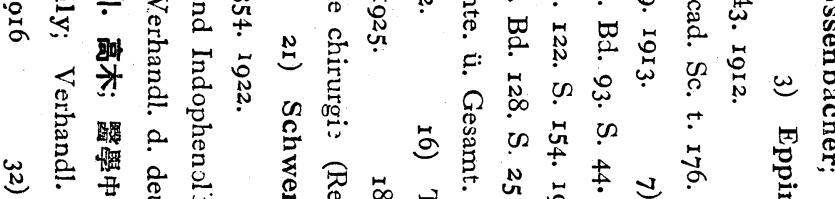

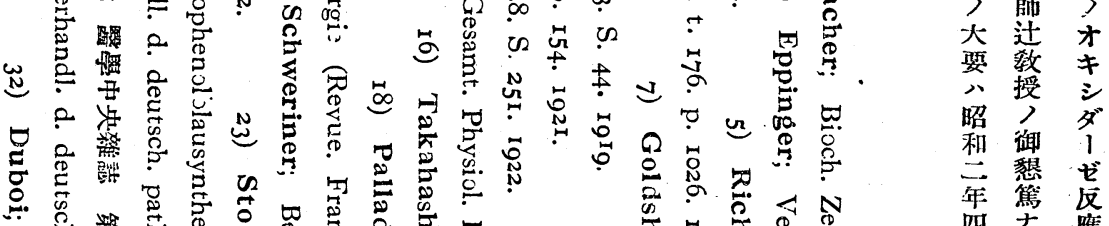

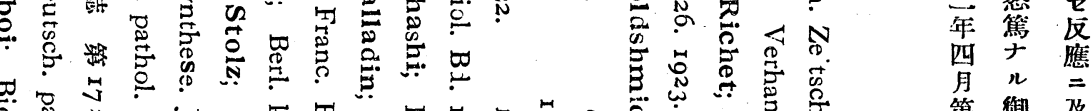

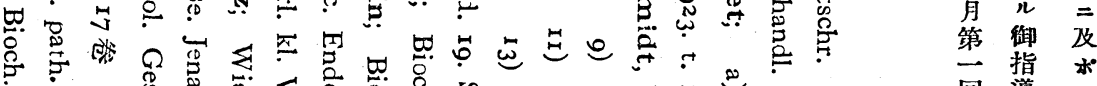

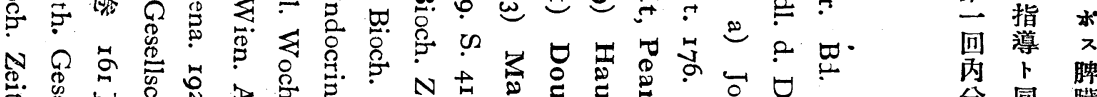

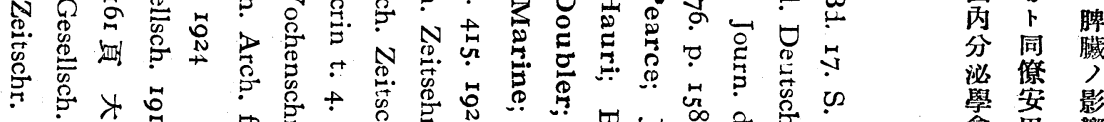

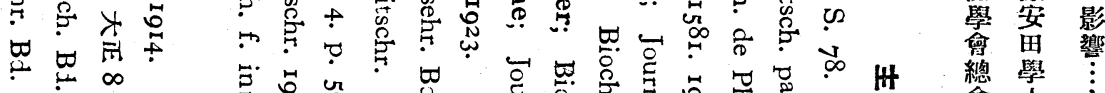

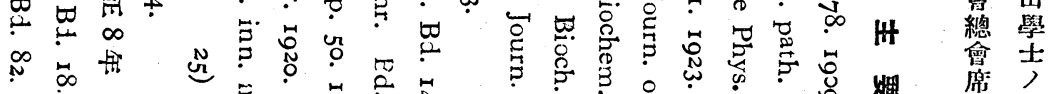

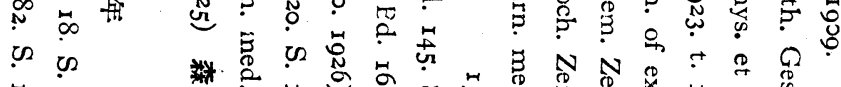

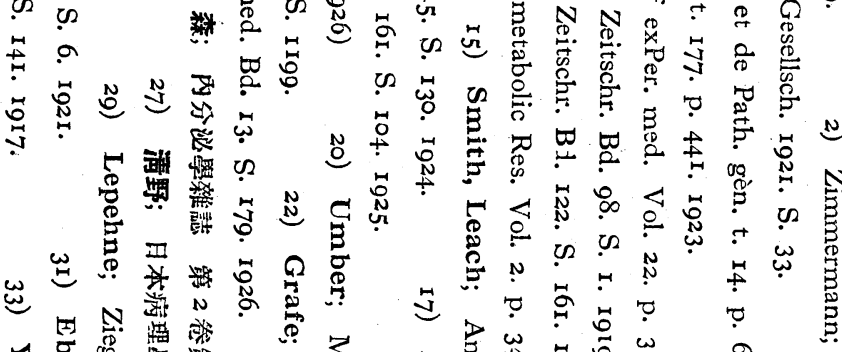

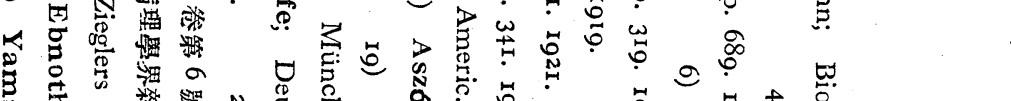

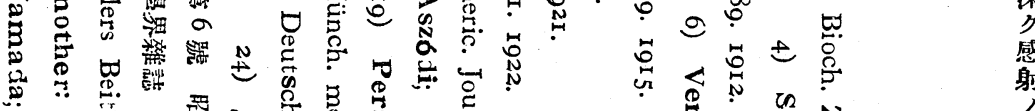

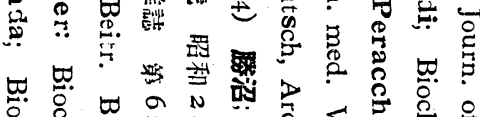

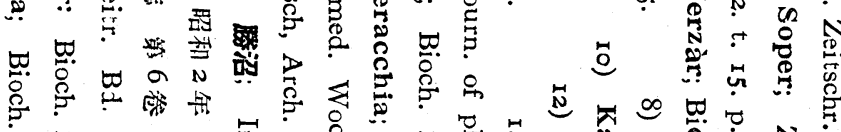

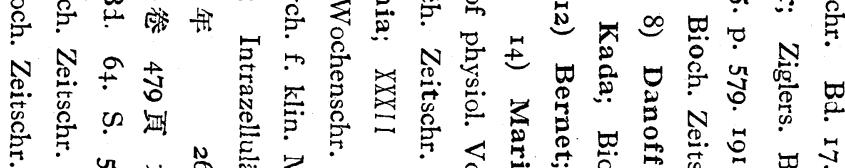

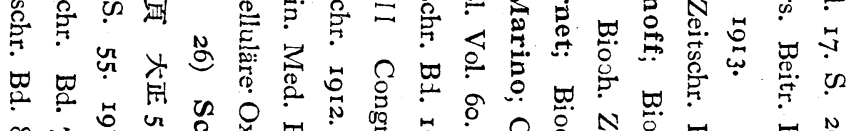

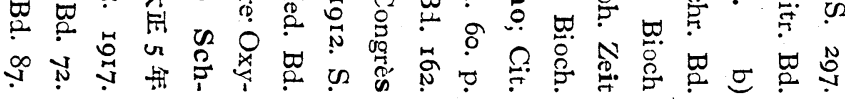




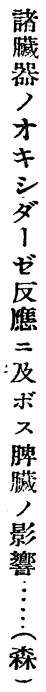

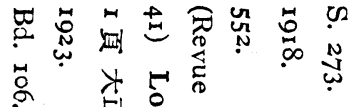

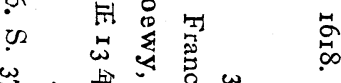

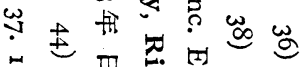

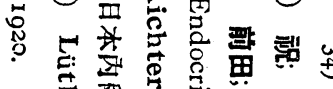
迹

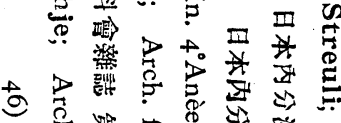

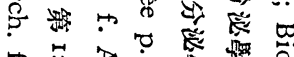

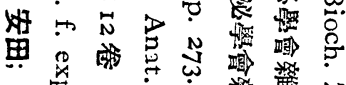

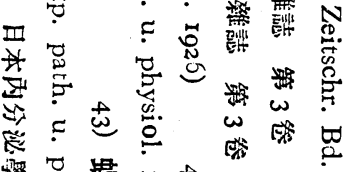

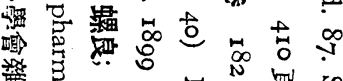

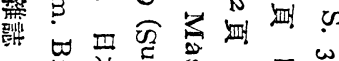

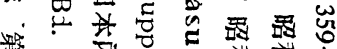

$\omega$ के 弯

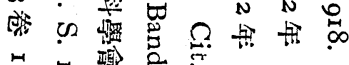

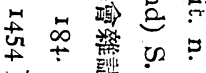

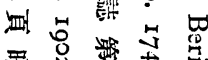

罚

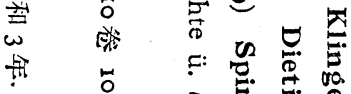

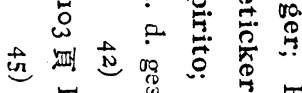

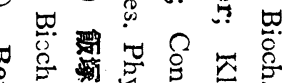

元
兄

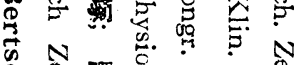

号点.

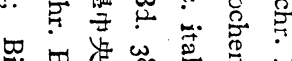

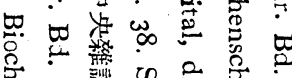

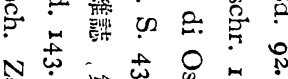

蛋

号总 N 
Schilddrüse deutlich nach I und auch 4 Wochen zu.

Bei Fütterung mit den Epithelkörperchen- und Thymussubstanzen ist die Jodgehaltzunahme nach $\mathrm{I}$ Woche gering, und mässig deutlich nach 4 Wochen. Die prozentuelle Zunahme ist nicht so stark wie bei der Fütterung mit Nebennieren oder der Insulininjektion.

Bei gleichzeitiger Darreichung von Jodkali mit den oben erwähnten Substanzen wird die Jodgehaltzunahme in der Schilddrüse deutlicher als bei der Fütterung nur mit diesen Substanzen. (Autoreferat.)

\title{
UEBER DEN EINFLUSS DER MILZ AUF DIE OXYDASEREAKTION DER EINZELNEN ORGANE.
}

\author{
Von \\ Dr. K. Mori.
}

(Aus der I. med. Klinik ber kaiserlichen Universität zu Kyoto. Direktor: Prof. Dr. K. Tsuji.)

In der früheren Mitteilung berichtete der Verfasser über die innige Beziehung zwischen den Funktionen der endokrinen Drüsen und der Oxydasereaktion der einzelnen Organe. Er stellte dabei sicher fest, dass Hyperthyreoidismus diese Reaktion begünstigt und Hypothyreoidismus sie hemmt. Neuerdings bestätigte Koliege Yasuda, cass die Reaktion bei der Fütterung mit Hodenpulver stärker und bei der Hodenexstirpation schwächer auftritt (s. Folia Endocrinologica Japonica Bd. III. H. 6.). Der Verfasser studierte diesmal bei Kaninchen mittelst der Vernonschen chemischen und Gierke-Gräffschen histologischen Methode den Einfluss der Milz auf die Oxydasereaktion. Als Versuchsmaterial wählte er das Herz, die Leber und die Niere aus.

Die Resultate sind die folgenden:

I) Bei den splenektomierten Tieren ist die Oxydasereaktion stärker 
als bei dem Kontrollen, und die Wirkung ist an der Leber am deutlichsten ausgeprägt. Daraus darf man schliessen, dass die Leber in einem innigen Zusammenhang mit der Milz steht.

2) Bei Tieren jedoch, die vorher thyreoidektomiert worden, hat die Milzexstirpation keinen erkennbaren Einfluss auf die Reaktion.

3) Bei der Fütterung mit Schilddrüsenpulver zeigen die milzlosen Tiere deutlichere Verstärkung der Reaktion als die nicht operierten. Besonders ist auch hier an der Leber die Wirknng auffallend.

4) Die Oxydasereaktion der milzlosen Tiere bleibt fast unverändert, wenn der Hoden exstirpiert ist.

5) Bei der Darreichung von Hodenpulver zeigen die milzlosen Kaninchen stärkere Reaktion als die nicht operierten Tiere.

6) Daraus lässt sich der Schluss ziehen, dass die Milz bezüglich der Oxydasereaktion in antagonistischem Verhältnis zu Schilddrüse und Hoden steht. 